\title{
In Vitro Cytotoxicity of Nanoparticles: A Comparison between Particle Size and Cell Type
}

\author{
Devashri Sahu, ${ }^{1}$ G. M. Kannan, ${ }^{1}$ Mukul Tailang, ${ }^{2}$ and R. Vijayaraghavan ${ }^{3}$ \\ ${ }^{1}$ Pharmacology and Toxicology Division, Defence Research and Development Establishment, Jhansi Road, Gwalior 474002, India \\ ${ }^{2}$ School of Studies in Pharmaceutical Sciences, Jiwaji University, Gwalior 474011, India \\ ${ }^{3}$ Saveetha University, Chennai 600077, India
}

Correspondence should be addressed to Mukul Tailang; mukultailang@yahoo.co.in

Received 14 March 2016; Revised 15 June 2016; Accepted 30 June 2016

Academic Editor: Nikolai Khlebtsov

Copyright (C) 2016 Devashri Sahu et al. This is an open access article distributed under the Creative Commons Attribution License, which permits unrestricted use, distribution, and reproduction in any medium, provided the original work is properly cited.

\begin{abstract}
The reduction in size of Zinc oxide $(\mathrm{ZnO})$ and Silicon dioxide $\left(\mathrm{SiO}_{2}\right)$ particles from micron to nano scale offers unique physical characteristics on one hand while making them cytotoxic on other hand. The present study was aimed at comparing cytotoxic effects of $\mathrm{ZnO}$ and $\mathrm{SiO}_{2}$ nanoparticles with their micron size and secondary aim was to compare responses of these particles to two different cell types, namely, human lung epithelial cells (L-132) and human monocytes (THP-1). The L-132 and THP-1 cells were exposed to nano and micron size of $\mathrm{ZnO}$ and $\mathrm{SiO}_{2}$ particles with different concentrations (5-500 $\left.\mu \mathrm{g} / \mathrm{mL}\right)$ for $24 \mathrm{~h}$, and cytotoxicity was analyzed by MTT assay, live-dead staining, and TC- 50 was calculated. $\mathrm{ZnO}$ and $\mathrm{SiO}_{2}$ particles showed concentration-dependent cytotoxicity in both cell lines. In size-dependent study, $\mathrm{ZnO}$ particles exhibited nearly equal toxicity profile in L-132 cells while in THP-1 cells nano $\mathrm{ZnO}$ showed more toxicity than its micron size. The $\mathrm{SiO}_{2}$ particles showed more toxicity in their nano size than micron size in both cell lines. Human monocytes, THP-1 cells, were more sensitive towards the toxicity of both particles than human lung cells, L-132. The results highlight the difference of cytotoxicity between particle sizes and differential sensitivity of cells towards the particles of same composition. In conclusion, $\mathrm{ZnO}$ and $\mathrm{SiO}_{2}$ particles exhibited concentration-dependent toxicity, which was more in their nano size than micron counterpart. However, the toxic response varies depending on type of cell exposed due to differential sensitivity.
\end{abstract}

\section{Introduction}

Rapid advances in the field of nanotechnology led to creation of nano-sized particles with very different chemical and physical properties as compared to particles in their bulk form [1]. Nanoparticles (NPs) possess diverse applications in various aspects of human life, from cosmetics and medical products to water purification and solar energy capture [2]. Due to increasing widespread contact and interaction of nanomaterials (NMs) with human body, the potential hazard to human health and safety has become the matter of concern $[3,4]$. Zinc oxide nanoparticles (ZnO-NPs) are commonly utilised for wide ranging applications from paint formulation and ceramic manufacture, to its use as a protective sunscreen in skin and hair care products [5]. Silica $\left(\mathrm{SiO}_{2}\right)$ is one of the most abundant oxides present in ambient air, typically in crystalline or amorphous form, and comprises up to $8 \%$ of all total airborne NPs [6]. Silica nanoparticles $\left(\mathrm{SiO}_{2}-\mathrm{NPs}\right)$ are produced on an industrial scale as additives to cosmetics, drugs, printer toners, varnishes, and food [7]. It is also widely used in biomedical applications as catalyst support, drug carrier [8], and gene delivery [9].

Despite the potential benefits of NPs, nanotoxicity has raised concern about its impact on human health. In NP research, particle size plays an important role in determining the particular biological behaviour of NMs. The large surface area of NPs makes the number of surface atoms or molecules increase exponentially to offer high reactivity. Numerous studies on the size and shape-dependent toxicity of NPs demonstrated biokinetic and biological impacts of NPs and exhibited altered cellular uptake, protein adsorption, accumulation in organelles, and distribution throughout the body [10-15]. One reason for these effects is the correlation between particle size and surface area. Recent studies showed 
varied in vitro cytotoxicity of NPs with respect to size and cell type. NMs like quantum dots to silica nanotubes demonstrated size-dependent toxicity $[10,13,16]$, while Zhang et al. [17] demonstrated differential toxicity of $\mathrm{ZnO}, \mathrm{TiO}_{2}, \mathrm{SiO}_{2}$, and $\mathrm{Al}_{2} \mathrm{O}_{3}$ NPs of the same size $(\sim 20 \mathrm{~nm})$ on human fetal lung fibroblast. Similarly, Yang et al. [18] also reported differential toxicity $\left(\mathrm{ZnO}>\mathrm{SWCNT}>\mathrm{CB}>\mathrm{SiO}_{2}\right)$ in primary mouse embryo fibroblast. In addition to the NP form and size, type of cell exposed to the NPs also plays an important role in cytotoxicity. This is due to the variation in cell physiology (e.g., epithelial or lymphoid), proliferation state (tumoral or resting cells), membrane characteristics, and phagocyte characteristics among different cell types [19]. Lanone et al. [20] showed that two human cell lines, namely, A549 and THP-1, exhibited difference in sensitivity towards the toxic effects of 24 NPs. Kroll et al. [21], during analysis of 23 engineered NMs on 10 different cell lines, illustrated that individual cell lines differed significantly in their response depending on particle type and toxicity end point measured. Sayes and collaborators showed diverse sensitivity in terms of viability and inflammation of different nanosized particles (carbonyl iron, silica, and Zinc oxide, 90-500 $\mathrm{nm}$ ) towards rat lung epithelial cells (L2 cell line) and primary alveolar macrophage [22].

In recent years, studies on size-dependent toxicity between micro- and nano-scale particles [23-28] showed that toxicity of NP is more compared to larger particles and affirmed the hypothesis that NPs in general are more potent in causing damage. All these evidences suggested that NPs of the same or different size exhibited varied toxic response but the studies with reference to their micron size are lacking. Though there are some similar reports with regard to toxicity of various sizes of $\mathrm{ZnO}$ and $\mathrm{SiO}_{2}$ NPs [27, 29-31], the comparative toxic effect of nano and micron size of $\mathrm{ZnO}$ and $\mathrm{SiO}_{2}$ particles is not yet studied properly and requires further complimentary investigations. Thus, the present study investigated comparative toxic potential of nano and micron size of particles in two different cell lines. In present study, $\mathrm{ZnO}$ and $\mathrm{SiO}_{2}$ particles of nano and micron size (ZnO: $100 \mathrm{~nm}$ and $5 \mu \mathrm{m}, \mathrm{SiO}_{2}: 10-20 \mathrm{~nm}$ and $10 \mu \mathrm{m}$ ) were selected. Among cell types, human lung epithelial cells (L-132) were selected because inhalation is one of the major routes of exposure for NPs and micro particles. Secondly, human monocytes (THP1) were chosen due to their role in clearing foreign particles [32].

\section{Materials and Methods}

2.1. Reagents. Dulbecco's modified eagle's medium (DMEM), Roswell park memorial institute (RPMI) medium, penicillinstreptomycin-neomycin solution, fetal bovine serum (FBS), 3-(4,5-dimethylthiazol-2-yl)-2,5-diphenyltetrazolium bromide (MTT), dimethyl sulfoxide (DMSO) and Zinc oxide nanopowder $<100 \mathrm{~nm}$, Zinc oxide $<5 \mu \mathrm{m}$, Silicon dioxide nanopowder $<10-20 \mathrm{~nm}$, and Silicon dioxide $\sim 0.5-10 \mu \mathrm{m}$ were purchased from Sigma-Aldrich (St. Louis, MO, USA).

2.2. Cell Culture. Human lung epithelial cells, L-132, and human monocytes, THP-1, were obtained from the National
Centre for Cell Sciences (NCCS) Pune and maintained as a monolayer and suspension culture in plastic tissue culture flasks in DMEM and RPMI medium, respectively, supplemented with $10 \% \mathrm{FBS}$ and $100 \mathrm{U} / \mathrm{mL}$ penicillin-streptomycinneomycin mixture. The cells were incubated at $37^{\circ} \mathrm{C}$, in a $100 \%$ humidified atmosphere containing $5 \% \mathrm{CO}_{2}$.

2.3. Characterization of Particles. Physicochemical properties of particles were analyzed using transmission electron microscopy (TEM), dynamic light scattering (DLS), and zeta potential analyzer. The morphology and size of NPs in the stock dispersion were determined by TEM. Dry powder of particles was suspended in distilled water at a concentration of $1 \mathrm{mg} / \mathrm{mL}$ and then sonicated at room temperature for $10 \mathrm{~min}$ to form a homogeneous suspension. After sonication, the TEM samples were prepared by drop coating of the stock suspension on carbon-coated copper grids. The films on the grids were allowed to dry prior to measurement. TEM measurements were performed at an accelerating voltage of $120 \mathrm{kV}$ (Model 1200EX, JEOL Ltd., Tokyo, Japan). ZetaPALS (Brookhaven Instruments Corporation, Holtsville, NY) was used to determine the hydrodynamic size by DLS technique $[27,28]$ and zeta potential of particle suspension in cell culture medium.

2.4. Particle Preparation and Exposure. Before particle exposure to the cells, the particles were dispersed in cell culture medium to a concentration of $2 \mathrm{mg} / \mathrm{mL}$. The dispersion was sonicated for $10 \mathrm{~min}$ using an ultrasonicator (Ultrasonic Homogenizer, Biologics Inc., USA.). Cells were plated into a 24 -well plate at a density of $1.0 \times 10^{6}$ cells/well. The particle concentration range was selected based on the minimum concentration showing low toxicity to concentration showing maximum toxicity. Between the two cell types chosen for study, THP-1 cells were more sensitive compared to L-132. Based on the results of screening study done by taking different concentration range of particles (data not shown), sensitivity of cells, and previous reports [29, 33-36], a concentration range was selected. The L-132 cells were exposed to both sizes of $\mathrm{ZnO}$ particles at concentration of 5, 25, 50, and $100 \mu \mathrm{g} / \mathrm{mL}$ and THP-1 cells were exposed to both sizes of $\mathrm{ZnO}$ particles at a concentration of $10,20,40,80$, and $100 \mu \mathrm{g} / \mathrm{mL}$ for $24 \mathrm{~h}$. Similarly L-132 and THP-1 cells were exposed to both sizes of $\mathrm{SiO}_{2}$ particles at a concentration range of 100 , 200,300,400, and $500 \mu \mathrm{g} / \mathrm{mL}$ and 10, 50, 100, 150, 200, and $250 \mu \mathrm{g} / \mathrm{mL}$, respectively, for $24 \mathrm{~h}$. Cells free of particles were used as control cells throughout each assay.

2.5. Cell Viability Assay. To assess effect of particles on the viability of both cell lines, MTT assay [37] was performed. Following exposure, the cells were incubated with MTT (20 $\mu \mathrm{L} /$ well of $5 \mathrm{mg} / \mathrm{mL}$ stock) for $4 \mathrm{~h}$. Mitochondrial dehydrogenases of viable cells reduce the yellowish water-soluble MTT to water-insoluble formazan crystals, which were solubilized with DMSO. The medium was then removed and $200 \mu \mathrm{L}$ of DMSO was added into each well to dissolve formazan crystals. For suspension culture, medium was removed by centrifugation and then DMSO was added. After 
TABLE 1: Particle characterization.

\begin{tabular}{lcccccc}
\hline Particles & Description & Average size $^{\mathrm{a}}$ & Size using TEM $^{\mathrm{b}}(\mathrm{nm})$ & Size in media $^{\mathrm{c}}(\mathrm{nm})$ & PDI $^{\mathrm{d}}$ & Zeta potential $^{\mathrm{e}}(\mathrm{mV})$ \\
\hline $\mathrm{Nano} \mathrm{ZnO}$ & Zinc oxide nanopowder & $<100 \mathrm{~nm}$ & $94.5 \pm 7.7$ & $253.6 \pm 2.5$ & $0.311 \pm 0.003$ & $17.50 \pm 1.17$ \\
$\mathrm{Micro} \mathrm{ZnO}$ & Zinc oxide & $<5 \mu \mathrm{m}$ & $158.3 \pm 9.8$ & $391.2 \pm 0.8$ & $0.266 \pm 0.006$ & $-8.60 \pm 3.29$ \\
$\mathrm{Nano}_{\mathrm{SiO}}$ & Silicon dioxide nanopowder & $<10-20 \mathrm{~nm}$ & $19.1 \pm 2.3$ & $98.5 \pm 11.1$ & $0.241 \pm 0.018$ & $-36.74 \pm 1.67$ \\
$\mathrm{Micro} \mathrm{SiO}_{2}$ & Silicon dioxide & $\sim 0.5-10 \mu \mathrm{m}$ & $530.9 \pm 3.9$ & $892.1 \pm 16.7$ & $0.172 \pm 0.005$ & $-33.21 \pm 5.63$ \\
\hline
\end{tabular}

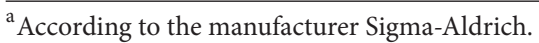

${ }^{\mathrm{b}}$ Using transmission electron microscopy.

$c, d$, and e Using Zeta PALS.

PDI: polydispersity index.

thorough mixing, optical density at $570 \mathrm{~nm}$ was detected by microplate reader (Biotek, USA). Interferences of particles were corrected by taking their absorption effect. Control values (without stimuli) were set at $100 \%$ viable and all values were expressed as a percentage of the control and respective TC-50 (particle concentration inducing 50\% cell mortality) concentrations were calculated by regression analysis using GraphPad Prism software.

2.6. Live-Dead Discrimination through Fluorescence Microscopy. After calculating TC-50 values of each sample, livedead assay was performed to confirm $50 \%$ cell mortality. The cells were exposed to particles with their respective TC-50 value. L-132 cells were exposed to nano and micron $\mathrm{ZnO}$ particles at concentration of $37.67 \mu \mathrm{g} / \mathrm{mL}$ and $35.04 \mu \mathrm{g} / \mathrm{mL}$, respectively, for $24 \mathrm{~h}$; similarly THP-1 cells were exposed to nano and micron $\mathrm{ZnO}$ particles at concentration of $17.69 \mu \mathrm{g} / \mathrm{mL}$ and $38.35 \mu \mathrm{g} / \mathrm{mL}$, respectively, for $24 \mathrm{~h}$. Likewise, L-132 cells were exposed to nano $\mathrm{SiO}_{2}$ at concentration of $312.5 \mu \mathrm{g} / \mathrm{mL}$ for $24 \mathrm{~h}$ while THP-1 cells were exposed to $17.69 \mu \mathrm{g} / \mathrm{mL}$ and $38.35 \mu \mathrm{g} / \mathrm{mL}$ of nano and micron $\mathrm{SiO}_{2}$ for $24 \mathrm{~h}$, respectively. Control and particle interacted cells were stained using Live/Dead double staining kit (Calbiochem, Germany) as per the manufacturer's instructions and then visualized under fluorescence microscope (Carl Zeiss, Germany).

\section{Statistical Analysis}

All experiments were done in triplicate and the results were presented as mean \pm SEM. The experimental data were analyzed by two-way analysis of variance (ANOVA) followed by Bonferroni posttest using GraphPad Prism software version 4.00 (GraphPad Software, San Diego, California, USA). Differences were considered significant at $p<0.05$. The TC-50 value was calculated using GraphPad Prism software (logarithmic transformation of $X$-values and nonlinear regression sigmoidal dose-response analysis with variable slope-with bottom and top constraints set at 0 and 100, resp.). Values were given $\pm 95 \%$ confidence intervals.

\section{Results}

4.1. Characterization of Particles. TEM analysis showed that the particles were nearly spherical and cubical in shape (Figure 1). The primary sizes of the particles estimated from
TEM images are presented in Table 1. The hydrodynamic sizes of the dispersed particles were larger than the particle size measured by TEM (Table 1). The zeta potential measurement showed strong agglomeration of particles in aqueous solutions. The observed values were $17.50 \mathrm{mV}$ for nano $\mathrm{ZnO}$, $-8.60 \mathrm{mV}$ for micron $\mathrm{ZnO},-36.74 \mathrm{mV}$ for nano $\mathrm{SiO}_{2}$, and $-33.21 \mathrm{mV}$ for micron $\mathrm{SiO}_{2}$ and these values showed that the charge of the hydrated particles was not high enough to repel each other by electrostatic forces.

4.2. Effect of $\mathrm{ZnO}$ Particles. ZnO particles showed concentration-dependent toxicity profile in both cell lines (Figures 2(a) and 2(b)). On exposure to L-132 cells, $\mathrm{ZnO}$ particles of both sizes illustrated significant decrease in cell viability at concentration from 25 to $100 \mu \mathrm{g} / \mathrm{mL}$. Nano $\mathrm{ZnO}$ and micron $\mathrm{ZnO}$ particles showed decrease in cell viability from $73 \%$ to $21 \%$ and $63 \%$ to $23 \%$, respectively, in L- 132 cells. Similar trend was observed in THP-1 cells, showing decrease in cell viability from $77 \%$ to $21 \%$ and $82 \%$ to $35 \%$ at concentration from 5 to $100 \mu \mathrm{g} / \mathrm{mL}$.

4.3. Effect of $\mathrm{SiO}_{2}$ Particles. $\mathrm{SiO}_{2}$ particles on interaction to both cell lines demonstrated concentration-dependent toxicity (Figures 3(a) and 3(b)). On exposure to L-132 cells, nano $\mathrm{SiO}_{2}$ particles showed significant reduction in cell viability from $44 \%$ to $33 \%$ at concentrations from 300 to $500 \mu \mathrm{g} / \mathrm{mL}$ but micron size of $\mathrm{SiO}_{2}$ particles showed less reduction in cell viability that is only up to $75 \%$. In case of THP-1 cells, nano and micron size $\mathrm{SiO}_{2}$ particles decreased the cell viability from $71 \%$ to $12 \%$ and $66 \%$ to $48 \%$, respectively, at concentration from 50 to $250 \mu \mathrm{g} / \mathrm{mL}$.

4.4. Relative Cytotoxicity. TC-50 values for all the particles were calculated from concentration response curve (Table 2). The cytotoxicity data and TC-50 values (Figures 2 and 3 and Table 2) varied significantly between particle size and cell type. The TC-50 values of nano and micron size $\mathrm{ZnO}$ particles in L-132 cells were nearly equal (namely, $37.67 \mu \mathrm{g} / \mathrm{mL}$ and $35.04 \mu \mathrm{g} / \mathrm{mL}$, resp.). However, in THP-1 cells, nano $\mathrm{ZnO}$ has lesser TC-50 value $(17.69 \mu \mathrm{g} / \mathrm{mL})$ than its micron size $(38.35 \mu \mathrm{g} / \mathrm{mL})$. In case of $\mathrm{SiO}_{2}$ particles, only nano $\mathrm{SiO}_{2}$ showed toxic effect on L-132 with TC-50 value of $312.5 \mu \mathrm{g} / \mathrm{mL}$ cells while its micron size exhibited relatively weak toxic effect only at higher concentrations and did not allow the calculation of TC-50 value. In contrast to these results, in 
TABLE 2: Calculated TC-50 concentrations.

\begin{tabular}{|c|c|c|c|c|}
\hline \multirow{2}{*}{ Cell type } & \multicolumn{2}{|c|}{$\mathrm{ZnO}$ particles } & \multicolumn{2}{|c|}{$\mathrm{SiO}_{2}$ particles } \\
\hline & Nano $\mathrm{ZnO}$ & Micro $\mathrm{ZnO}$ & Nano $\mathrm{SiO}_{2}$ & Micro $\mathrm{SiO}_{2}$ \\
\hline L-132 & $\begin{array}{c}37.67 \mu \mathrm{g} / \mathrm{mL} \\
\text { (30.62 to } 46.35) \\
\end{array}$ & $\begin{array}{c}35.04 \mu \mathrm{g} / \mathrm{mL} \\
(29.76 \text { to } 41.25)\end{array}$ & $\begin{array}{c}312.5 \mu \mathrm{g} / \mathrm{mL} \\
(280.1 \text { to } 348.7)\end{array}$ & nd \\
\hline THP-1 & $\begin{array}{c}17.69 \mu \mathrm{g} / \mathrm{mL} \\
\text { (15.75 to } 19.87)\end{array}$ & $\begin{array}{c}38.35 \mu \mathrm{g} / \mathrm{mL} \\
(24.52 \text { to } 58.13)\end{array}$ & $\begin{array}{c}88.39 \mu \mathrm{g} / \mathrm{mL} \\
(75.74 \text { to } 103.2)\end{array}$ & $\begin{array}{c}231.0 \mu \mathrm{g} / \mathrm{mL} \\
(144.4 \text { to } 369.6)\end{array}$ \\
\hline
\end{tabular}

nd: not determined (TC-50 can not be calculated).

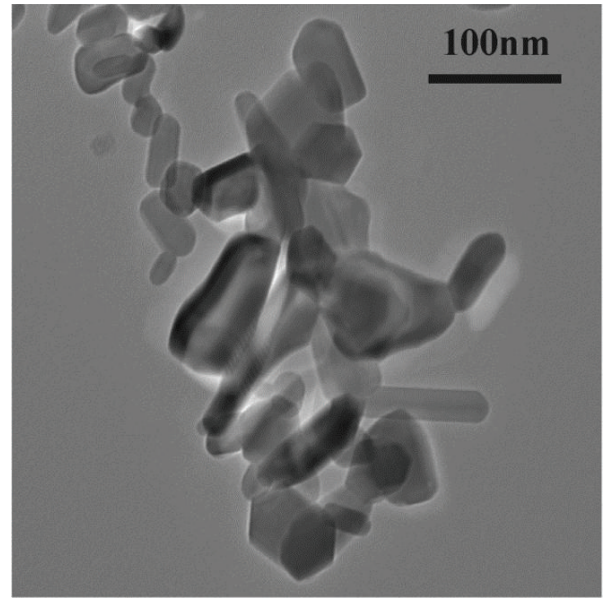

(a)

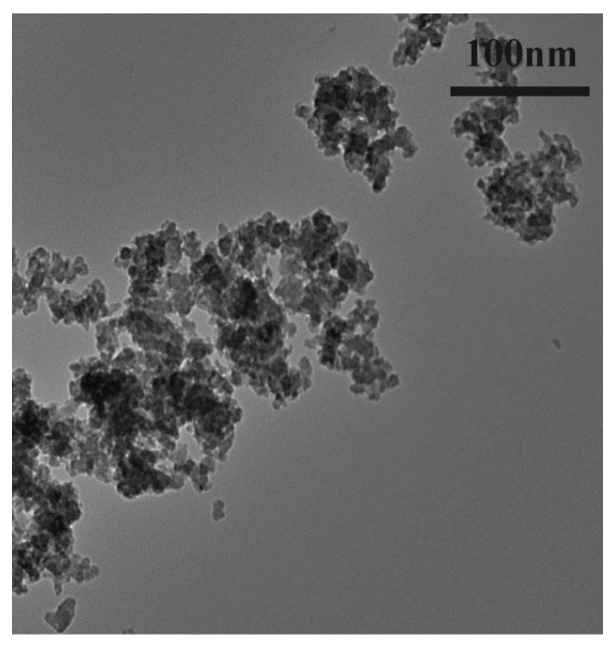

(c)

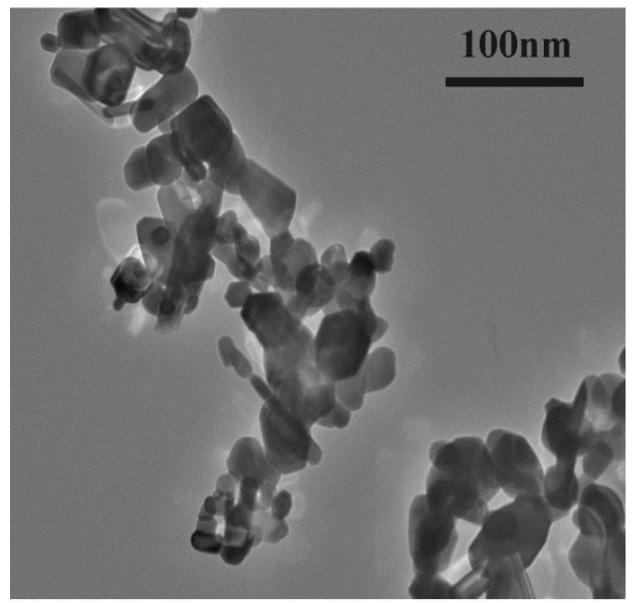

(b)

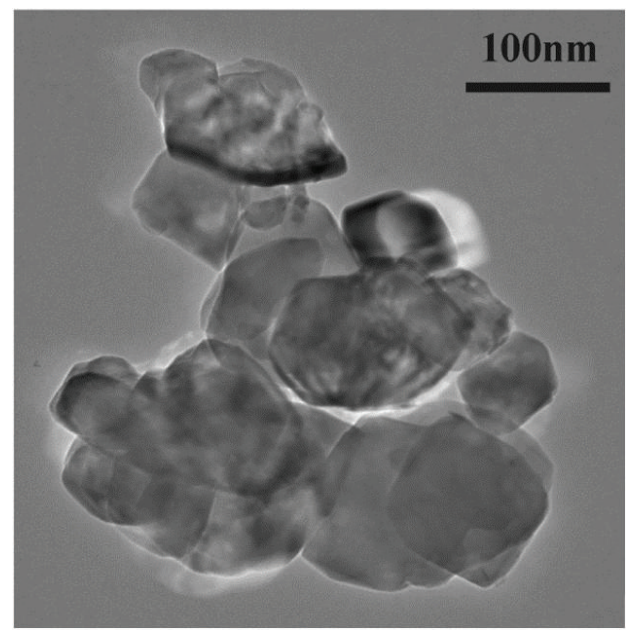

(d)

Figure 1: Transmission electron microscope (TEM) images of (a) nano $\mathrm{ZnO}$, (b) micro $\mathrm{ZnO}$, (c) nano $\mathrm{SiO}_{2}$, and (d) micro $\mathrm{SiO}_{2}$. Scale bar is $100 \mathrm{~nm}$ for all images.

THP-1 cells the TC-50 values of nano and micron size $\mathrm{SiO}_{2}$ particles were $88.39 \mu \mathrm{g} / \mathrm{mL}$ and $231.0 \mu \mathrm{g} / \mathrm{mL}$, respectively.

4.5. Live-Dead Assay. The $50 \%$ cell mortality was further confirmed by discrimination of live/dead cells at respective TC50 values using fluorescent microscopy. Live cells appeared green (Figures 4 and 5) and cells with compromised membrane were seen red in colour. The fluorescent microscopic pictures depicted $50 \%$ cell mortality as indicated by red staining with propidium iodide at its TC-50 values.

\section{Discussion}

The small size and the relatively large surface area of NPs resulted in increased toxicity when compared to particles in micrometer size. Therefore, the present study was carried out with objectives to compare the toxic potentials of nano and 


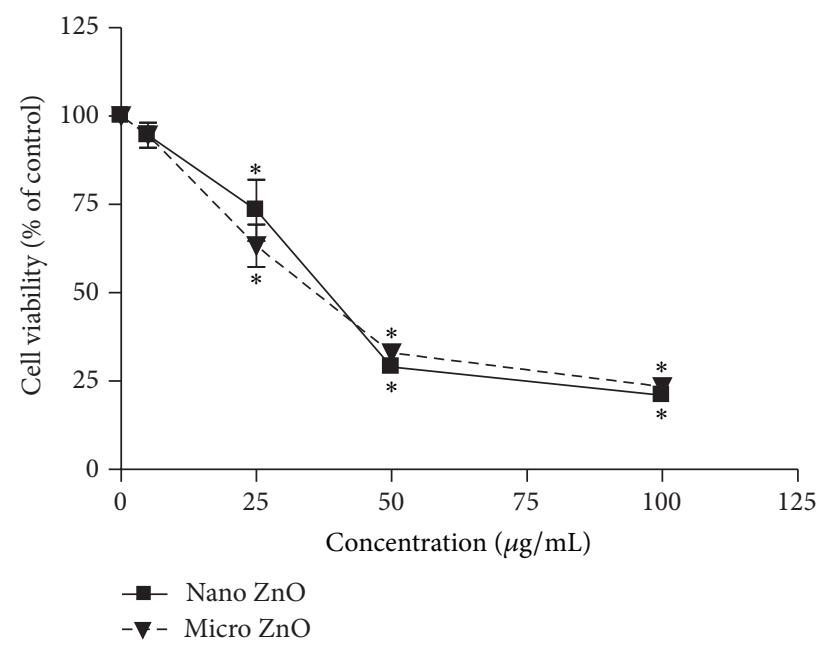

(a)

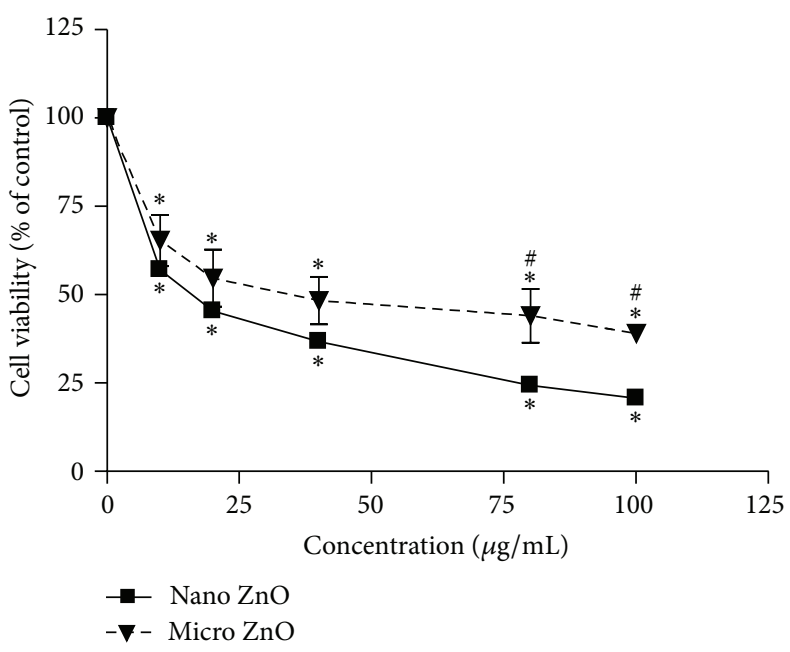

(b)

Figure 2: Cytotoxicity of ZnO particle in (a) L-132 cells and (b) THP-1 cells. Concentration-response curve to obtain TC-50 value. Results were mean \pm SEM of three independent experiments each carried out in triplicate. ${ }^{*} p<0.05$ in comparison to untreated controls. ${ }^{\#} p<0.05$ indicates significant difference between nano and micron size group.

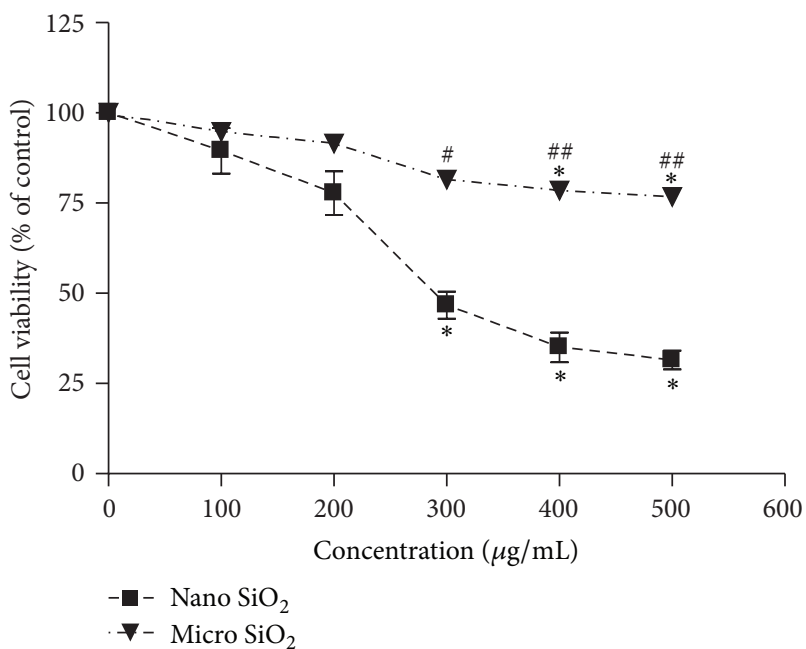

(a)

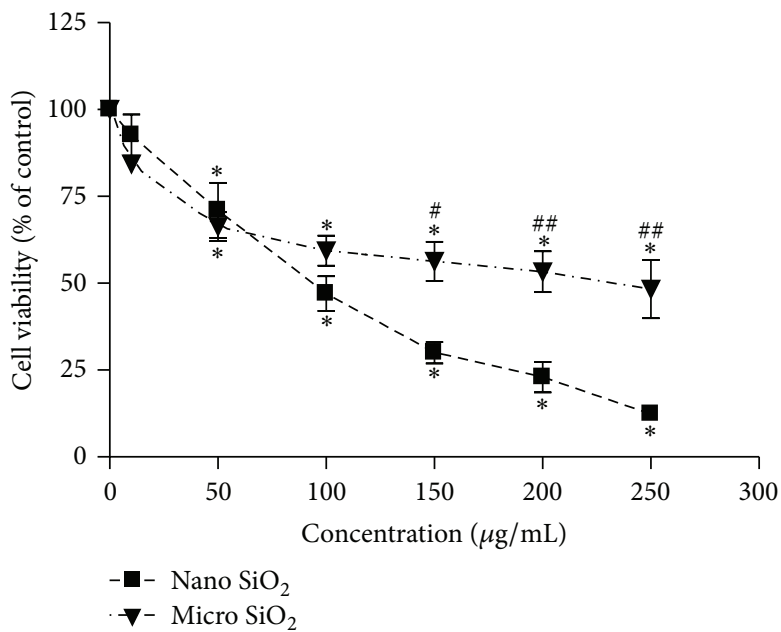

(b)

Figure 3: Cytotoxicity of $\mathrm{SiO}_{2}$ particle in (a) L-132 cells and (b) THP-1 cells. Concentration-response curve to obtain TC-50 value. Results were mean \pm SEM of three independent experiments each carried out in triplicate. ${ }^{*} p<0.05$ in comparison to untreated controls. ${ }^{\#} p<0.05$ and ${ }^{\# \#} p<0.01$ indicate significant difference between nano and micron size group.

micron size of $\mathrm{ZnO}$ and $\mathrm{SiO}_{2}$ particulates on exposure to human cell lines.

The physicochemical characteristics of nano and micron particles of both $\mathrm{ZnO}$ and $\mathrm{SiO}_{2}$ samples revealed that the primary size of micron $\mathrm{ZnO}$ and $\mathrm{SiO}_{2}$ particles provided by the supplier was not compatible with the measurements made in laboratory. The supplier reported that the mean size of micron $\mathrm{ZnO}$ particle was $<5 \mu \mathrm{m}$ and micron $\mathrm{SiO}_{2}$ particle was in the range of 0.5 to $10 \mu \mathrm{m}$; however, the measured particle sizes (Table 1) by TEM were not identical for micron sizes of both $\mathrm{ZnO}$ and $\mathrm{SiO}_{2}$ particles. The average size of nano $\mathrm{ZnO}$ and nano $\mathrm{SiO}_{2}$ was in agreement with the size provided by the supplier. In comparison to measurements in the dry phase (by TEM) the mean particle sizes and size distributions of particles (measured by DLS) were enhanced when measured in aqueous media. Due to high specific surface area and high surface energy level, NPs have the propensity to aggregate together to form micro-size particles that are more stable in the environment $[38,39]$. To minimize the effects of particles aggregation and sedimentation, colloidal suspension of particles was always freshly prepared and sonicated before each experiment.

Nanomaterials induce cell specific responses resulting in variable toxicity [40-42]. Our results indicated that the sizes 


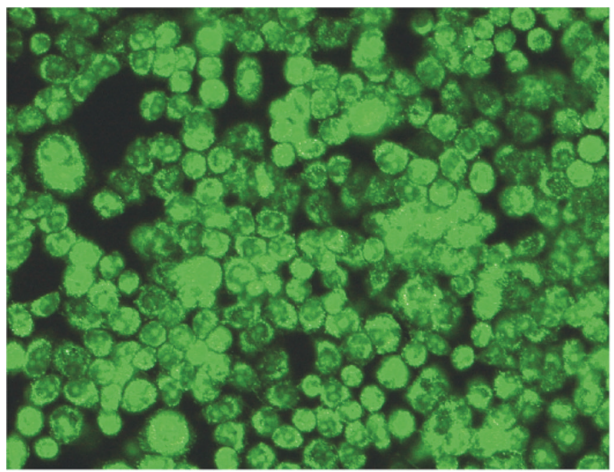

(a)

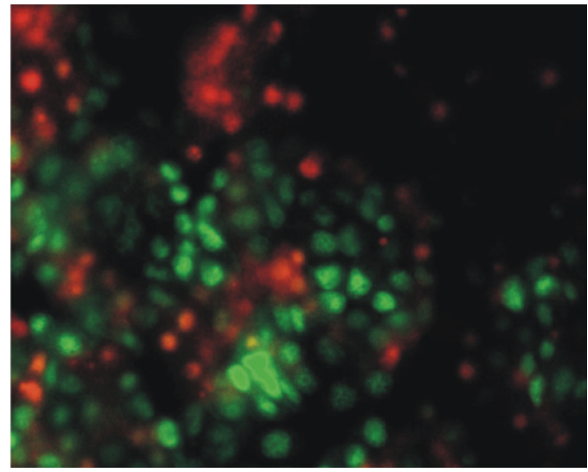

(b)

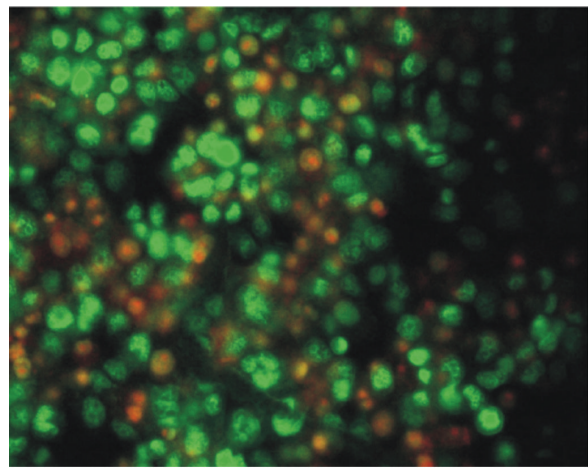

(d)

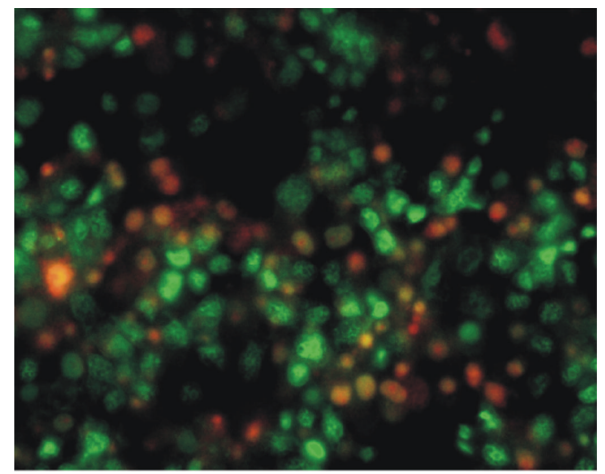

(c)

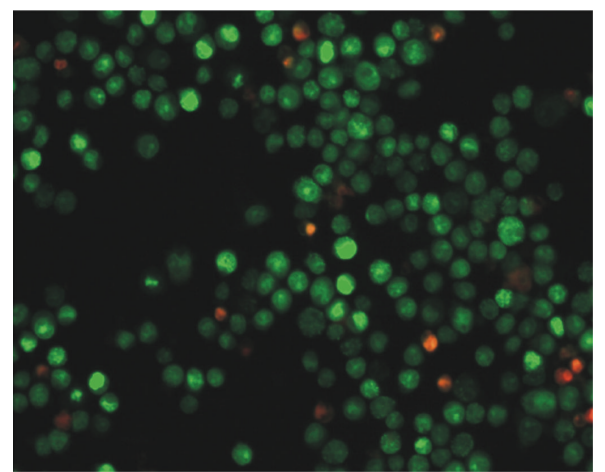

(e)

FIGURE 4: Fluorescent microscopic images of L-132 cells stained with Cyto-dye and propidium iodide. Cells were exposed at TC-50 concentrations of $\mathrm{ZnO}$ and $\mathrm{SiO}_{2}$ particles for $24 \mathrm{~h}$. Live cells appeared green and dead cells were seen red in colour. Cells were cultured with (a) DMEM only (control); (b) nano $\mathrm{ZnO}$; (c) micro $\mathrm{ZnO}$; (d) nano $\mathrm{SiO}_{2}$; and (e) TC-20 (i.e., $485 \mu \mathrm{g} / \mathrm{mL}$ ) of micro $\mathrm{SiO}_{2}$. The magnification was $400 \mathrm{x}$.

of particles as well as the target cell type are critical determinants of intracellular responses and degree of cytotoxicity. In the present study, exposure of $\mathrm{ZnO}$ and $\mathrm{SiO}_{2}$ particles caused concentration-dependent cytotoxicity as revealed by cell viability assay. The comparative results indicated that nano $\mathrm{ZnO}$ exhibited more toxicity than its micron size in THP-1 cells. The results were consistent with Prach et al. [32] who demonstrated higher toxicity of ZnO-NPs on human $\mathrm{T}$ cells than $\mathrm{ZnO}$ microparticles and supported the findings. However, in L-132 cells, equal toxicity profile was observed with nano and micron size of $\mathrm{ZnO}$. These results were in agreement with the results of Lin et al. [30] and Deng et al. [43] who found similar toxicity $\mathrm{ZnO}$ particles of different sizes irrespective of size. The equal toxicity profile of $\mathrm{ZnO}$ particles observed in this study is possibly due to the lack of difference in nano and micron size of $\mathrm{ZnO}$ as revealed from its TEM and DLS data.

In case of $\mathrm{SiO}_{2}$ particles, nano $\mathrm{SiO}_{2}$ exhibited more toxicity than its micron size as reported in previous investigations $[28,31,35]$ and corroborates the findings. $\mathrm{SiO}_{2}$ particles 


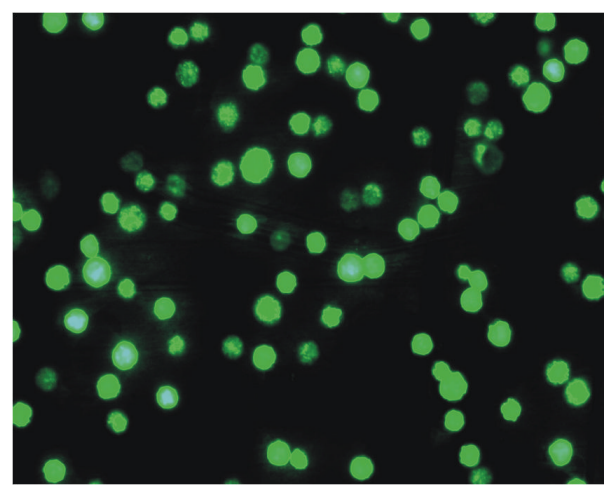

(a)

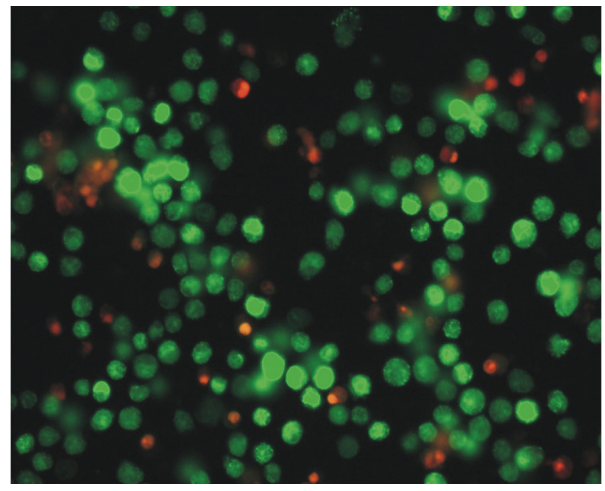

(b)

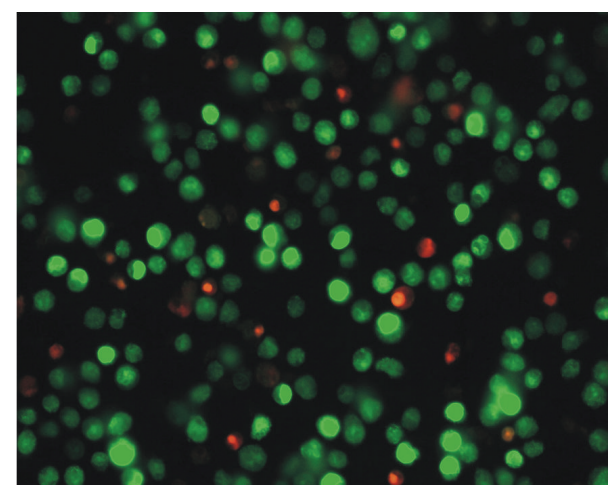

(d)

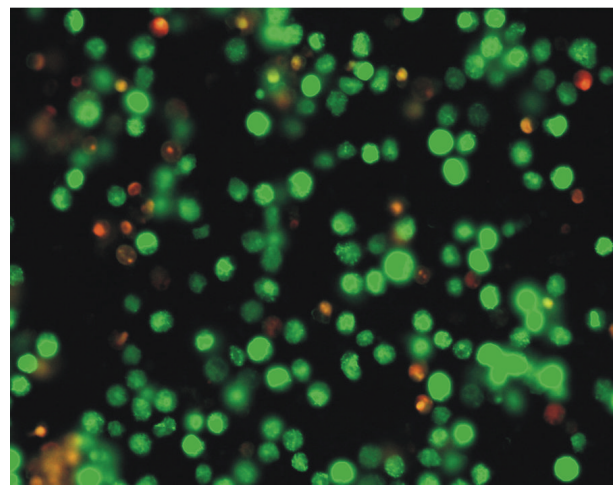

(c)

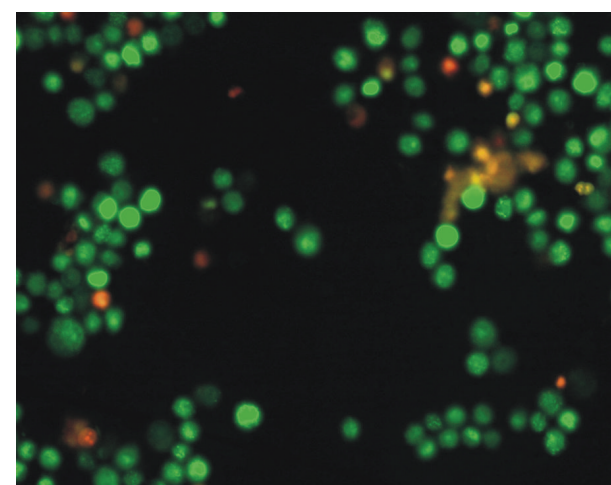

(e)

FIgURE 5: Fluorescent microscopic images of THP-1 cells stained with Cyto-dye and propidium iodide. Cells were exposed at TC-50 concentrations of $\mathrm{ZnO}$ and $\mathrm{SiO}_{2}$ particles for $24 \mathrm{~h}$. Live cells appeared green and dead cells were seen red in colour. Cells were cultured with (a) RPMI medium only (control); (b) nano $\mathrm{ZnO}$; (c) micro $\mathrm{ZnO}$; (d) nano $\mathrm{SiO}_{2}$; (e) micro $\mathrm{SiO}_{2}$. The magnification was 400x.

possessed more toxic effect on THP-1 cells than on L-132 cells. A comparable response between the cell lines suggested difference in sensitivity of cells towards the same particles. The TC-50 values obtained with L-132 cells were higher than those obtained with THP-1 cells and revealed more sensitivity of THP-1 cells than L-132 cells. These results were consistent with the findings of Lanone et al. [20] who also reported differential sensitivity of human alveolar and macrophage cell line towards various NPs.

To summarize, there is a strong size-selective difference in NP toxicity. As the cellular targets are not the same, one can expect the cellular response not to be identical, depending on the cell death mechanism [44]. Possible reason to explain the cellular target specificities even for similarly sized particles may be attributed to the function of phagocytosis, which characterizes monocytes (THP-1 cells), but not lung epithelial cells [20]. It is the preliminary study to compare cytotoxicity between particle sizes, although, to find out possible mechanism in its differential toxicity, further studies need to be carried out. Hence the parameters like target cell type and size of the particle have to be carefully taken into account when assessing NP toxicity. 


\section{Competing Interests}

The authors declare that they have no competing interests.

\section{Acknowledgments}

The authors acknowledge Advanced Instrumentation Research Facility (AIRF), Jawaharlal Nehru University (JNU), New Delhi, India, for NP characterization by TEM. The hydrodynamic size and zeta potential measurements of particles were performed using facilities at CeNSE, funded by Department of Information Technology, Govt. of India and Institute of Science, Bangalore, India.

\section{References}

[1] A. S. Edelstein and R. C. Cammaratra, Nanomaterials: Synthesis, Properties and Applications, CRC Press, New York, NY, USA, 2nd edition, 1998.

[2] N. Staggers, T. McCasky, N. Brazelton, and R. Kennedy, "Nanotechnology: the coming revolution and its implications for consumers, clinicians, and informatics," Nursing Outlook, vol. 56, no. 5, pp. 268-274, 2008.

[3] S. J. Klaine, P. J. J. Alvarez, G. E. Batley et al., "Nanomaterials in the environment: behavior, fate, bioavailability, and effects," Environmental Toxicology and Chemistry, vol. 27, no. 9, pp. 18251851, 2008.

[4] P. Schulte, C. Geraci, R. Zumwalde, M. Hoover, and E. Kuempel, "Occupational risk management of engineered nanoparticles," Journal of Occupational and Environmental Hygiene, vol. 5, no. 4, pp. 239-249, 2008.

[5] Z. Fan and J. G. Lu, "Zinc oxide nanostructures: synthesis and properties," Journal of Nanoscience and Nanotechnology, vol. 5, no. 10, pp. 1561-1573, 2005.

[6] M. Balduzzi, M. Diociaiuti, B. De Berardis, S. Paradisi, and L. Paoletti, "In vitro effects on macrophages induced by noncytotoxic doses of silica particles possibly relevant to ambient exposure," Environmental Research, vol. 96, no. 1, pp. 62-71, 2004.

[7] P. H. M. Hoet, I. Brüske-Hohlfeld, and O. V. Salata, "Nanoparticles-known and unknown health risks," Journal of Nanobiotechnology, vol. 2, article 12, 2004.

[8] I. Roy, T. Y. Ohulchanskyy, D. J. Bharali et al., "Optical tracking of organically modified silica nanoparticles as DNA carriers: a nonviral, nanomedicine approach for gene delivery," Proceedings of the National Academy of Sciences of the United States of America, vol. 102, no. 2, pp. 279-284, 2005.

[9] Z. S. Csogor, M. Nacken, M. Sameti, C.-M. Lehr, and H. Schmidt, "Modified silica particles for gene delivery," Materials Science and Engineering: C, vol. 23, no. 1-2, pp. 93-97, 2003.

[10] N. Lewinski, V. Colvin, and R. Drezek, "Cytotoxicity of nanoparticles," Small, vol. 4, no. 1, pp. 26-49, 2008.

[11] B. D. Chithrani, A. A. Ghazani, and W. C. W. Chan, "Determining the size and shape dependence of gold nanoparticle uptake into mammalian cells," Nano Letters, vol. 6, no. 4, pp. 662-668, 2006.

[12] C. J. Murphy, A. M. Gole, J. W. Stone et al., "Gold nanoparticles in biology: beyond toxicity to cellular imaging," Accounts of Chemical Research, vol. 41, no. 12, pp. 1721-1730, 2008.
[13] A. Nan, X. Bai, S. J. Son, S. B. Lee, and H. Ghandehari, "Cellular uptake and cytotoxicity of silica nanotubes," Nano Letters, vol. 8, no. 8, pp. 2150-2154, 2008.

[14] B. D. Chithrani and W. C. W. Chan, "Elucidating the mechanism of cellular uptake and removal of protein-coated gold nanoparticles of different sizes and shapes," Nano Letters, vol. 7, no. 6, pp. 1542-1550, 2007.

[15] S. Wang, W. Lu, O. Tovmachenko, U. S. Rai, H. Yu, and P. C. Ray, "Challenge in understanding size and shape dependent toxicity of gold nanomaterials in human skin keratinocytes," Chemical Physics Letters, vol. 463, no. 1-3, pp. 145-149, 2008.

[16] Y. Pan, S. Neuss, A. Leifert et al., "Size-dependent cytotoxicity of gold nanoparticles," Small, vol. 3, no. 11, pp. 1941-1949, 2007.

[17] X. Q. Zhang, L. H. Yin, M. Tang, and Y. P. Pu, " $\mathrm{ZnO}, \mathrm{TiO}_{2}, \mathrm{SiO}_{2}$, and $\mathrm{Al}_{2} \mathrm{O}_{3}$ nanoparticles-induced toxic effects on human fetal lung fibroblasts," Biomedical and Environmental Sciences, vol. 24, no. 6, pp. 661-669, 2011.

[18] H. Yang, C. Liu, D. Yang, H. Zhang, and Z. Xi, "Comparative study of cytotoxicity, oxidative stress and genotoxicity induced by four typical nanomaterials: the role of particle size, shape and composition," Journal of Applied Toxicology, vol. 29, no. 1, pp. 69-78, 2009.

[19] B. Díaz, C. Sánchez-Espinel, M. Arruebo et al., "Assessing methods for blood cell cytotoxic responses to inorganic nanoparticles and nanoparticle aggregates," Small, vol. 4, no. 11, pp. 20252034, 2008.

[20] S. Lanone, F. Rogerieux, J. Geys et al., "Comparative toxicity of 24 manufactured nanoparticles in human alveolar epithelial and macrophage cell lines," Particle and Fibre Toxicology, vol. 6, article 14, 2009.

[21] A. Kroll, C. Dierker, C. Rommel et al., "Cytotoxicity screening of 23 engineered nanomaterials using a test matrix of ten cell lines and three different assays," Particle and Fibre Toxicology, vol. 8, no. 1, article 9, 2011.

[22] C. M. Sayes, K. L. Reed, and D. B. Warheit, "Assessing toxicity of fine and nanoparticles: comparing in vitro measurements to in vivo pulmonary toxicity profiles," Toxicological Sciences, vol. 97, no. 1, pp. 163-180, 2007.

[23] D. M. Brown, M. R. Wilson, W. MacNee, V. Stone, and K. Donaldson, "Size-dependent proinflammatory effects of ultrafine polystyrene particles: a role for surface area and oxidative stress in the enhanced activity of ultrafines," Toxicology and Applied Pharmacology, vol. 175, no. 3, pp. 191-199, 2001.

[24] B. Wang, W.-Y. Feng, T.-C. Wang et al., "Acute toxicity of nanoand micro-scale zinc powder in healthy adult mice," Toxicology Letters, vol. 161, no. 2, pp. 115-123, 2006.

[25] H. L. Karlsson, J. Gustafsson, P. Cronholm, and L. Möller, "Size-dependent toxicity of metal oxide particles-A comparison between nano- and micrometer size," Toxicology Letters, vol. 188, no. 2, pp. 112-118, 2009.

[26] K. Midander, P. Cronholm, H. L. Karlsson et al., "Surface characteristics, copper release, and toxicity of nano- and micrometer-sized copper and copper(ll) oxide particles: a crossdisciplinary study," Small, vol. 5, no. 3, pp. 389-399, 2009.

[27] D. B. Warheit, C. M. Sayes, and K. L. Reed, "Nanoscale and fine zinc oxide particles: can in vitro assays accurately forecast lung hazards following inhalation exposures?" Environmental Science and Technology, vol. 43, no. 20, pp. 7939-7945, 2009.

[28] Y. Li, L. Sun, M. Jin et al., "Size-dependent cytotoxicity of amorphous silica nanoparticles in human hepatoma HepG2 cells," Toxicology in Vitro, vol. 25, no. 7, pp. 1343-1352, 2011. 
[29] W. Lin, Y.-W. Huang, X.-D. Zhou, and Y. Ma, "In vitro toxicity of silica nanoparticles in human lung cancer cells," Toxicology and Applied Pharmacology, vol. 217, no. 3, pp. 252-259, 2006.

[30] W. Lin, Y. Xu, C.-C. Huang et al., "Toxicity of nano- and microsized $\mathrm{ZnO}$ particles in human lung epithelial cells," Journal of Nanoparticle Research, vol. 11, no. 1, pp. 25-39, 2009.

[31] Y. Ye, J. Liu, M. Chen, L. Sun, and M. Lan, "In vitro toxicity of silica nanoparticles in myocardial cells," Environmental Toxicology and Pharmacology, vol. 29, no. 2, pp. 131-137, 2010.

[32] M. Prach, V. Stone, and L. Proudfoot, "Zinc oxide nanoparticles and monocytes: impact of size, charge and solubility on activation status," Toxicology and Applied Pharmacology, vol. 266, no. 1, pp. 19-26, 2013.

[33] M. Ahamed, M. J. Akhtar, M. Raja et al., "Zinc oxide nanorod induced apoptosis via p53, bax/bcl-2 and survivin pathways in human lung cancer cells: role of oxidative stress," International Journal of Nanomedicine, vol. 7, pp. 845-857, 2012.

[34] F. Tian, T. Zhu, and Y. Shang, "Intracellular influx of calcium induced by quartz particles in alveolar macrophages," Toxicology and Applied Pharmacology, vol. 242, no. 2, pp. 173-181, 2010.

[35] K. M. Waters, L. M. Masiello, R. C. Zangar et al., "Macrophage responses to silica nanoparticles are highly conserved across particle sizes," Toxicological Sciences, vol. 107, no. 2, pp. 553-569, 2009.

[36] J. Zhang, W. Song, J. Guo et al., "Toxic effect of different $\mathrm{ZnO}$ particles on mouse alveolar macrophages," Journal of Hazardous Materials, vol. 219-220, pp. 148-155, 2012.

[37] F. Denizot and R. Lang, "Rapid colorimetric assay for cell growth and survival: modifications to the tetrazolium dye procedure giving improved sensitivity and reliability," Journal of Immunological Methods, vol. 89, no. 2, pp. 271-277, 1986.

[38] Y. T. He, J. Wan, and T. Tokunaga, "Kinetic stability of hematite nanoparticles: the effect of particle sizes," Journal of Nanoparticle Research, vol. 10, no. 2, pp. 321-332, 2008.

[39] A. R. Petosa, D. P. Jaisi, I. R. Quevedo, M. Elimelech, and N. Tufenkji, "Aggregation and deposition of engineered nanomaterials in aquatic environments: role of physicochemical interactions," Environmental Science and Technology, vol. 44, no. 17, pp. 6532-6549, 2010.

[40] K. Soto, K. M. Garza, and L. E. Murr, "Cytotoxic effects of aggregated nanomaterials," Acta Biomaterialia, vol. 3, no. 3, pp. 351-358, 2007.

[41] I. Papageorgiou, C. Brown, R. Schins et al., "The effect of nanoand micron-sized particles of cobalt-chromium alloy on human fibroblasts in vitro," Biomaterials, vol. 28, no. 19, pp. 2946-2958, 2007.

[42] S. Park, Y. K. Lee, M. Jung et al., "Cellular toxicity of various inhalable metal nanoparticles on human alveolar epithelial cells," Inhalation Toxicology, vol. 19, no. 1, pp. 59-65, 2007.

[43] X. Deng, Q. Luan, W. Chen et al., "Nanosized zinc oxide particles induce neural stem cell apoptosis," Nanotechnology, vol. 20, no. 11, article 115101, 2009.

[44] J. Weyermann, D. Lochmann, and A. Zimmer, "A practical note on the use of cytotoxicity assays," International Journal of Pharmaceutics, vol. 288, no. 2, pp. 369-376, 2005. 

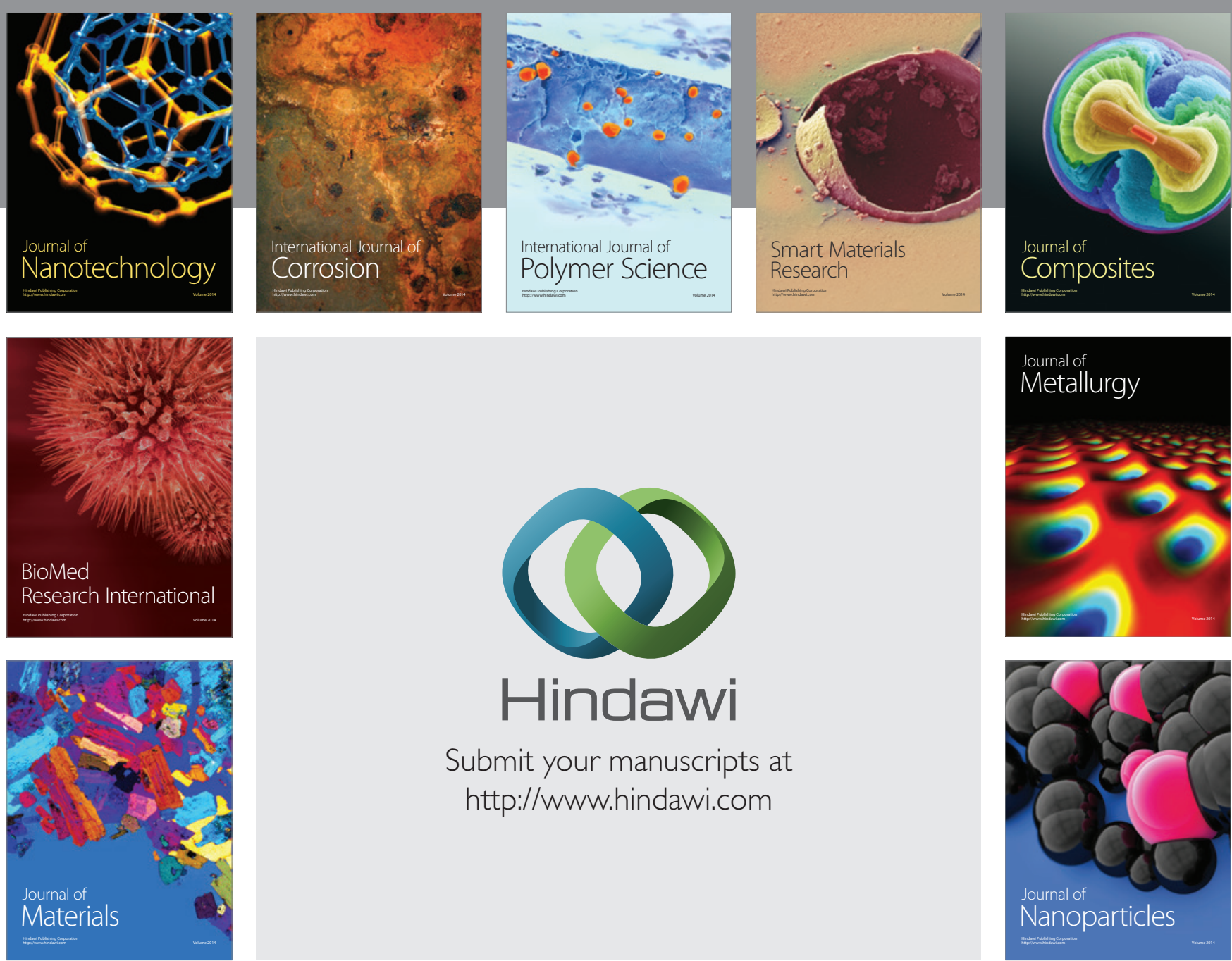

\section{Hindawi}

Submit your manuscripts at

http://www.hindawi.com

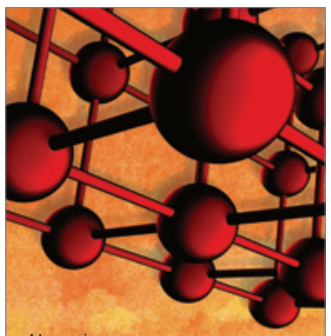

Materials Science and Engineering
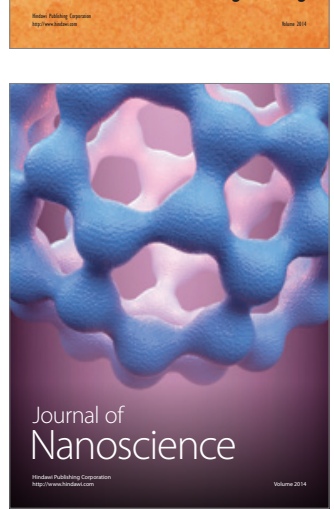
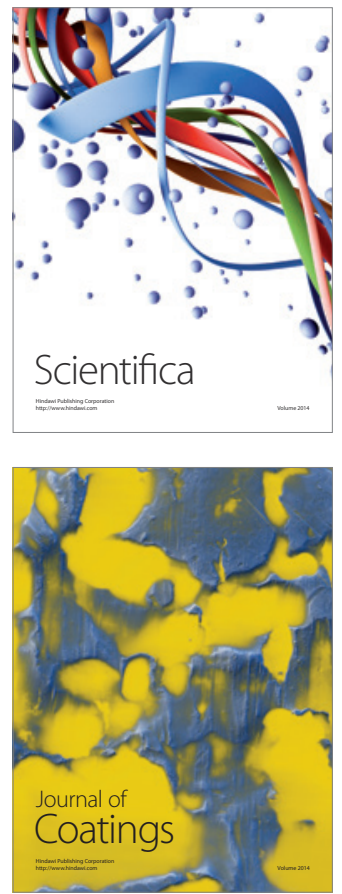
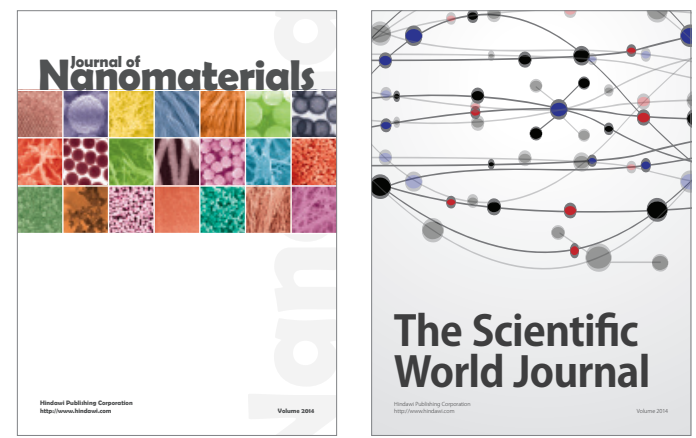

The Scientific World Journal
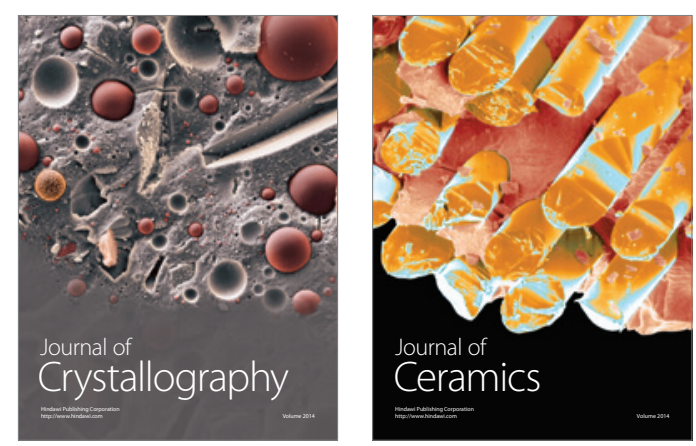
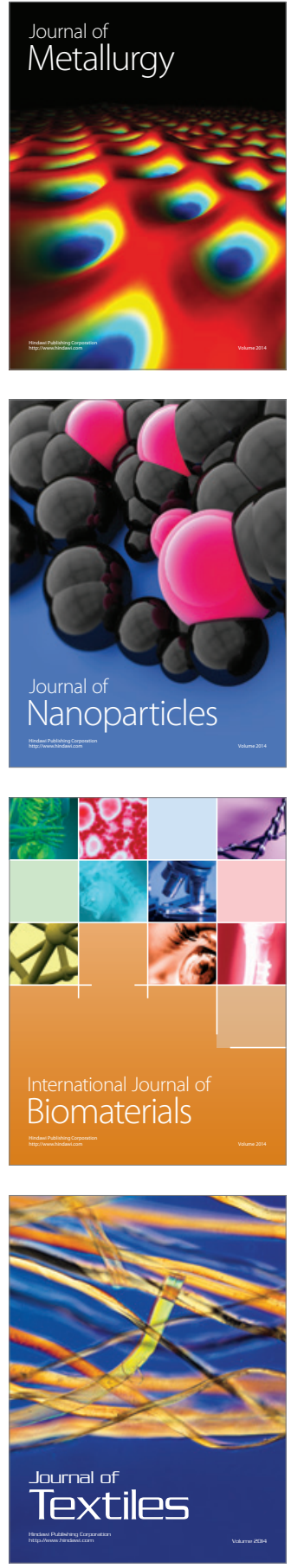